\title{
Clear cell tumor of the lung: a case report and literature review
}

\author{
Guang-xian Wang ${ }^{1}$, Dong Zhang ${ }^{1}$, Xin-wei Diao ${ }^{2}$ and Li Wen ${ }^{1 *}$
}

\begin{abstract}
Clear cell tumor of the lung is a rare and benign pulmonary tumor; only sporadic cases have been reported. Here, we report the case of a 38-year-old man with recurrent cough, blood-streaked sputum and left chest pain. A chest computed tomography scan showed a round, homogeneous pulmonary mass in the left lower lobe, which exhibited intense heterogeneous enhancement in the arterial phase and homogeneous in the delay phase after injecting a contrast agent. The patient underwent a fine-needle aspiration biopsy and was diagnosed as having a benign clear cell tumor of the lung. The clinical presentation and radiographic investigation of this tumor are summarized in this paper to recognize this rare disease. Interestingly, we found some differences with previously reported cases.
\end{abstract}

Keywords: Clear cell tumor, Sugar tumor, Lung

\section{Background}

Clear cell tumor of the lung (CCTL) is a rare and benign pulmonary neoplasm, which was originally described by Liebow and Castleman in 1963 [1]. CCTL most likely arises from perivascular epithelioid cells (PECs) [2-4]. As it contains abundant cytoplasmic periodic acid-Schiff (PAS)-positive glycogen, CCTL has been termed "sugar tumor" [5]. The tumor cells show immunoreactivity for the S-100 protein and HMB-45 and no cytokeratin reactivity, which establish a definitive diagnosis [6]. Although the tumor has been well defined, only sporadic cases have been reported in the literature. Here, we report on a CCTL case and summarize a literature review of 55 CCTL cases. Our aims were to identify the clinical and radiological features of CCTL and determine the effect of CCTL tumor size.

\section{Case presentation}

A 38-year-old man was admitted to our hospital because of recurrent cough, blood-streaked sputum for 2 months, left chest pain for 10 days, and worsening health for 3 days. The patient, who had no known family history of cancer, was an 18 pack/year smoker. He did not

\footnotetext{
* Correspondence: xqwgxll@163.com

'Department of Radiology, Xinqiao Hospital, Third Military Medical University, Chongqing 400037, China

Full list of author information is available at the end of the article
}

report any fever, night sweating, chest tightness, weight loss, or wheezing. A physical examination did not show any abnormalities, and the results of laboratory studies were unremarkable. Chest non-enhanced computed tomography (CT) scans showed a demarcated, round, homogeneous lesion of approximately $3.4 \mathrm{~cm}$ in diameter without evidence of calcification, necrosis, cavitation, or satellite lesions in the left lower lobe (Figure 1A), with a CT value of 46.6 Hounsfield units. A contrast-enhanced CT scan of the solitary pulmonary mass showed intense heterogeneous enhancement in the arterial phase (Figure 1B) and a homogeneous nature in the delay phase (delay 150 seconds) (Figure 1C). Abdominal CT scans showed no evidence of renal disease.

Using an 18-gauge needle, a CT-guided biopsy of the lung at our institution was performed to determine the nature of the lesion. Light microscopy and immunohistochemical studies were performed. The material for pathological examination that was obtained at the biopsy was fixed in $10 \%$ formalin and embedded in paraffin. For light microscopy, $5-\mu \mathrm{m}$ thick sections were cut from the inclusions and stained with hematoxylin and eosin and PAS. For PAS staining, the slide was fixed with $4 \%$ paraformaldehyde, oxidized in $1 \%$ periodic acid for 5 minutes and then washed and treated with Schiff's reagent for 15 minutes. The slide was subsequently treated for color development in $\mathrm{dH}_{2} \mathrm{O}$ for 5 to 10 minutes and assessed 


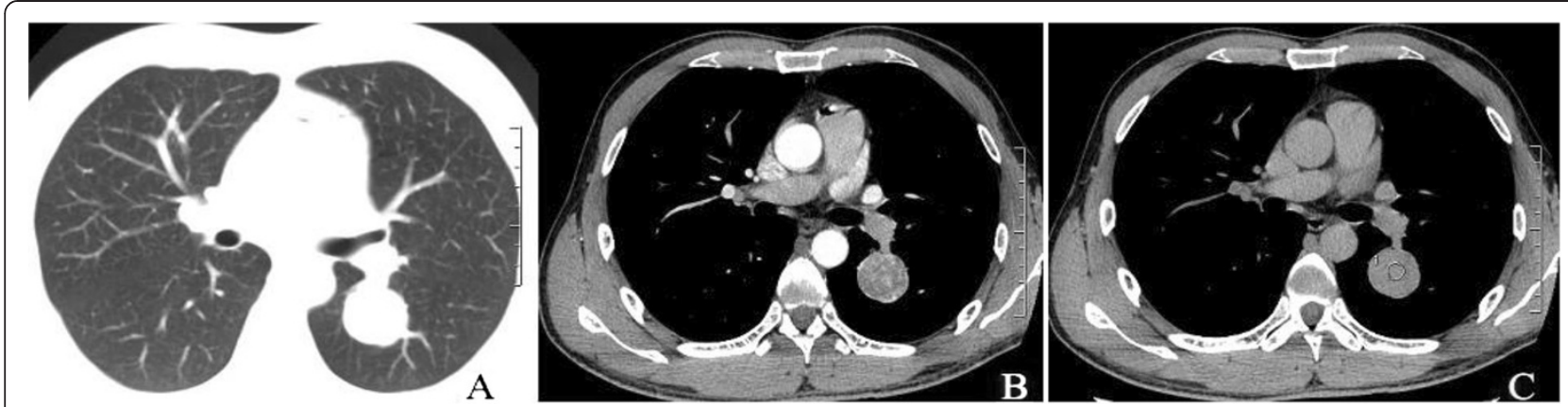

Figure 1 Chest computed tomography findings of the tumor. (A) Chest plain computed tomography scan shows a solitary, rounded, smooth-surfaced, homogenous density mass of approximately $3.4 \mathrm{~cm}$ in diameter in the left lower lobe (S6). (B) The contrast-enhanced arterial phase shows intense heterogeneous enhancement measuring 67.2 to 128.0 Hounsfield units. (C) The contrast-enhanced delay phase shows an isodense nodule measuring 66.3 Hounsfield units.

under a light microscope. For immunohistochemistry, paraffin sections were treated with monoclonal antibodies against HMB-45, vimentin, CD34, S-100 protein, cytokeratin, desmin, CD68, EMA, RCC, and TTF-1. The antigen-antibody complexes were visualized using the streptavidin-biotin-peroxidase complex method.

Histologically, the lesion consisted of sheets of neoplastic cells. Plump, short, polygonal, and spindle-shaped cells with distinctive cell borders and mildly pleiomorphic nuclei were observed. These cells were surrounded by thin-walled blood vessels of various sizes (Figure 2A). No signs of necrosis and no mitotic figures were seen. The clear cytoplasm contained numerous glycogen granules, as demonstrated by PAS stain (Figure 2B). The immunohistochemical studies showed strong immunoreactivity for HMB-45 (Figure 2C) and showed a positive reaction to vimentin, $\mathrm{CD} 34$, and $\mathrm{S}-100$ protein but no reactivity for cytokeratin, desmin, CD68, EMA, RCC, and TTF-1. Based on these findings, the lesion was diagnosed as CCTL. The patient underwent a left thoracotomy, and a wedge resection was performed to remove the tumor, whose pathologic findings were concordant with the biopsy specimen. No evidence of recurrence or metastatic disease was evident during the 12-month follow-up period after the surgery.

\section{Literature review}

PubMed and Google were searched in March 2012 using the following terms in various combinations: benign lung tumor, clear cell tumor, sugar tumor, CCTL and PEComa. Only full-text English studies were reviewed.

A total of 56 CCTL cases (including the present case) were reviewed [2,4,6-27]. The collected data included patient age, gender, symptoms, and tumor location, contour, and density. Table 1 illustrates the clinical characteristics of the CCTL patients and radiological features of the tumors. The relationships between tumor size and the parameters of symptoms, location, contour, and density were assessed with Spearman's correlation. The statistical differences in symptoms and tumor contour were compared between the $\geq 2.2 \mathrm{~cm}$ tumor size group and the $<2.2 \mathrm{~cm}$ tumor size group using the chi-squared test. Statistical analyses were performed with the Statistical Package for the Social Sciences (SPSS, Chicago IL, U.S.A;
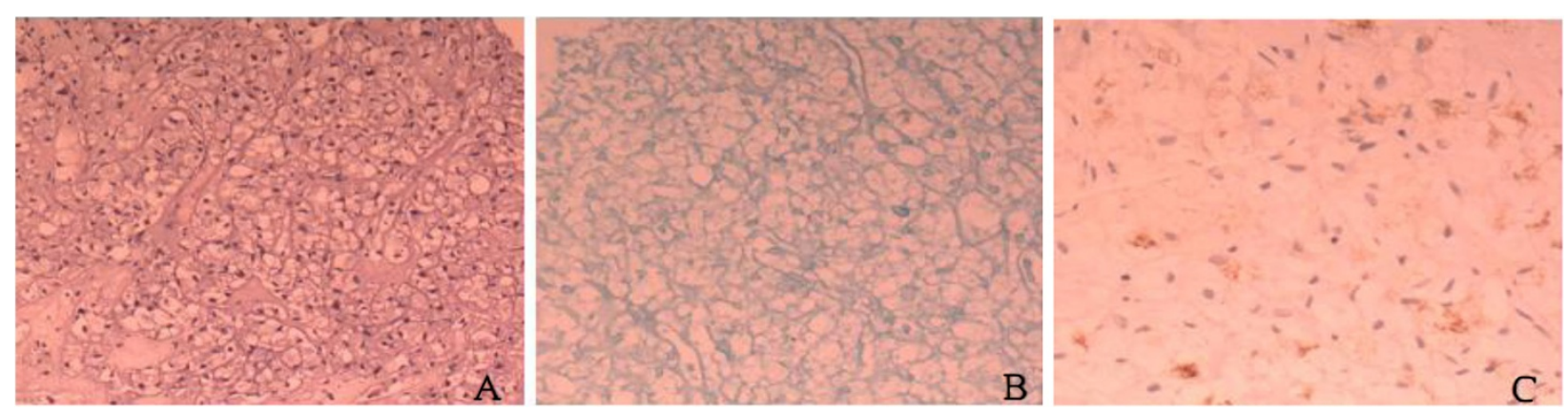

Figure 2 Microscopic and immunohistochemistry findings. (A) Histopathological examination shows diffuse growth of rounded or oval cells with abundant clear cytoplasm, distinctive cell borders, and thin-walled blood vessels (hematoxylin and eosin, X200. (B) Most neoplastic clear cells have intracytoplasmic periodic acid-Schiff-positive glycogen granules (streptavidin-perosidase, $\times 200$. (C) Many tumor cells show cytoplasmic staining for HMB-45 (streptavidin-perosidase, $\times 200$ ). 
Table 1 Composite presentation of 56 CCTL cases [2,4,6-27]

\begin{tabular}{|c|c|}
\hline & $n(\%)$ \\
\hline \multicolumn{2}{|l|}{ Age (years) } \\
\hline$<40$ & $12 / 56(21.4)$ \\
\hline $40-70$ & $41 / 56(73.2)$ \\
\hline$>70$ & $3 / 56(5.4)$ \\
\hline \multicolumn{2}{|l|}{ Sex } \\
\hline Male & 29/56 (51.8) \\
\hline Female & $27 / 56(48.2)$ \\
\hline \multicolumn{2}{|l|}{ Symptoms } \\
\hline Asymptomatic & $37 / 56(66.1)$ \\
\hline Symptomatic & 19/56 (33.9) \\
\hline \multicolumn{2}{|l|}{ Location } \\
\hline LU & 9/52 (17.3) \\
\hline $\mathrm{LL}$ & $19 / 52(36.5)$ \\
\hline $\mathrm{RU}$ & 8/52 (15.4) \\
\hline RM & 3/52 (5.8) \\
\hline$R L$ & $13 / 52(25.0)$ \\
\hline NR & 4 \\
\hline \multicolumn{2}{|l|}{ Size $(\mathrm{cm})$} \\
\hline$<2.2$ & 29/56 (51.8) \\
\hline$\geq 2.2$ & $27 / 56(48.2)$ \\
\hline \multicolumn{2}{|l|}{ Contour } \\
\hline Round & 39/44 (88.6) \\
\hline Lobulated & $5 / 44(11.4)$ \\
\hline NR & 12 \\
\hline \multicolumn{2}{|l|}{ Density } \\
\hline Homogeneous & $42 / 51(82.4)$ \\
\hline Heterogeneous & 9/51 (17.6) \\
\hline$N R$ & 5 \\
\hline
\end{tabular}

LU, left upper lobe; LL, left lower lobe; RU, right upper lobe; RM, right middle lobe; RL, right lower lobe; NR, not recorded.

version 17.0 ). A $P$ value $<0.05$ was considered statistically significant.

Spearman's correlation analysis showed that tumor size was most frequently associated with symptoms and tumor contours (Table 2), whereas it has no significant correlation with location and density (Table 2). There were significant statistical differences in patient symptoms and

Table 2 Correlation between tumor size and symptoms, location, contour, and density

\begin{tabular}{lcc}
\hline & Correlation coefficient $\left(\mathbf{r}_{\mathbf{s}}\right)$ & $\boldsymbol{P}$ \\
\hline Symptom & 0.475 & 0.000 \\
Location & -0.041 & 0.763 \\
Contour & 0.344 & 0.01 \\
Density & 0.052 & 0.702 \\
\hline
\end{tabular}

Table 3 Correlation between tumor size and symptoms

\begin{tabular}{|c|c|c|c|}
\hline Size & Asymptomatic* & Symptomatic & Total \\
\hline$<2.2 \mathrm{~cm}$ & 25 & 4 & 29 \\
\hline$\geq 2.2 \mathrm{~cm}$ & 12 & 15 & 27 \\
\hline
\end{tabular}

tumor contour between the $\geq 2.2 \mathrm{~cm}$ group and the $<2.2$ $\mathrm{cm}$ group. Patients were more likely to experience symptoms $\left(\mathrm{chi}^{2}=56.000, P=0.000\right.$, Table 3$)$, and the tumor was more likely to be lobulated $\left(\mathrm{chi}^{2}=72.333, P=0.000\right.$, Table 4) if the tumor size was $\geq 2.2 \mathrm{~cm}$.

\section{Discussion}

CCTL is a rare benign pulmonary neoplasm originally described in 1963 by Liebow and Castleman [1]. Since that time, fewer than 60 cases have been reported in the English literature. CCTL can occur in any age group (range 8 to 73 years), with equal sex prevalence $[7,8,10,16,17,23,25,26]$ or a slight female predominance $[4,9,14,24,28]$. However, in our study, males were slightly more prone to CCTL than females (29/27). Most patients were asymptomatic; only a few patients displayed symptoms (for example, chest pain, back pain, breathlessness, sense of suppression, cough, pneumonia, fever, bloody sputum or hemoptysis) [6-15,24]. These symptoms were usually nonspecific, as most cases were discovered incidentally on routine chest radiographs or CT scans.

Radiographically, CCTL presents as a rounded, smoothwalled peripheral parenchymal nodule, without evidence of cavitation or calcification. There are no specific lobar distributions according to the literature $[7,8,16,17]$. In our study, nodules were generally found in the lower lobes of both lungs (32/52) and were unrelated to vessels or major bronchi. The tumor sizes ranged from $1 \mathrm{~mm}$ [29] to $12 \mathrm{~cm}$ [10]. In our literature review, we found that certain clinicopathologic features such as a diameter $>2.5 \mathrm{~cm}$, the presence of symptoms, and extensive necrosis or abundant mitoses visible under an optical microscope were associated with more aggressive behavior [13,17,21,27]. Our results showed that the tumor size was most closely correlated with patients' symptoms and tumor contour: significant statistical differences were found between the $\geq 2.2$ $\mathrm{cm}$ group and the $<2.2 \mathrm{~cm}$ group. The results suggested that patients should undergo operation or follow-up if the tumor size was $\geq 2.2 \mathrm{~cm}$. However, the lesion density was not correlated with tumor size.

Table 4 Correlation between tumor size and contour

\begin{tabular}{lcccc}
\hline Size & Round & Lobulated & NR & Total \\
\hline$<2.2 \mathrm{~cm}$ & 24 & 0 & 5 & 29 \\
$\geq 2.2 \mathrm{~cm}$ & 15 & 5 & 7 & 27 \\
\hline
\end{tabular}


Based on a contrast-enhanced CT scan, the main features of this case were the intense heterogeneous enhancement in the arterial phase and washout in the delay phase, which were consistent with a previous report [17]. This CT finding appears to be a result of the vascular stroma $[8,13,17,24]$, although occasionally, for an unknown reason, there is no enhancement [22]. The characteristics of CCTL, which have been described as having an intense heterogeneous enhancement in the arterial phase and homogeneous in the delay phase, have not been previously reported. The CT enhancement features indicate the malignant potential of this mass rather than a benign nodule [17]. The preoperative accurate CT diagnosis of this disease is difficult.

CCTL is usually diagnosed by thoracotomy, lobectomy, and segmentectomy. Partial resection and enucleation have been reported as treatments in previous studies [22]. Only one case of CCTL was diagnosed pre-operatively by a transbronchial lung biopsy [19], and three cases (including the case reported here) by fine-needle aspiration biopsy $[9,23]$. The biology of this tumor has traditionally been considered benign, but malignant behavior has been occasionally reported. A 1988 report described a patient with CCTL who died from metastatic CCTL [30], and two other reports described this tumor with rapid growth $[5,26]$. Our patient was a heavy smoker with a lung mass, which exhibited an intense post-contrast enhancement in the arterial phase and washout in the delay phase on CT scan and was considered to have a malignant potential. Surgical treatment was suggested.

Macroscopically, CCTL predominantly appears as wellcircumscribed, peripheral nodules measuring $\leq 3 \mathrm{~cm}$ in diameter; cut surfaces are typically homogeneous and glistening, without evidence of hemorrhage, necrosis, cavitation, or calcification [8,17]. Histologically, the nodules are composed of mitotically inactive round or oval cells with clear or granular eosinophilic cytoplasm and distinct cell borders, with characteristic intervening thinwalled sinusoidal vessels; spindle cells may be observed occasionally [9]. PAS stain shows glycogen granules in the cytoplasm of these clear cells, which is why they are referred to as sugar tumors [5]. The clear cell tumor has to be differentiated from other malignant clear-cell tumors, particularly unusual primary clear cell adenocarcinoma of the lung and metastatic renal cell carcinoma, both of which can have a bland morphologic appearance and, therefore, can mimic CCTL. The tumor cells in both primary and secondary clear cell adenocarcinomas of the lung are positive for cytokeratin, whereas CCTL cells are always non-reactive for cytokeratin [22]. In our case, the diagnosis was based on the typical histology picture of the tumor, the positivity for PAS and HMB-45, and the absence of clinical signs of a renal tumor. We believe that the joint application of these markers can distinguish
CCTL from other pulmonary neoplasms with greater precision [25].

\section{Conclusions}

In summary, we reported a case of CCTL and a literature review of 55 CCTL cases. We analyzed the patient's clinical characteristics, the tumor's radiological features, and the effects of CCTL tumor size. We conclude that the tumor has three characteristics: (1) most of the patients are middle-aged and elderly people (with slightly more males than females) and are generally asymptomatic; (2) the tumor, which is usually located in both lower lungs, is round and homogeneous density on plain CT scan image; and (3) tumors $\geq 2.2 \mathrm{~cm}$ in diameter grow lobulated and have more aggressive symptoms.

\section{Consent}

Written informed consent was obtained from the patient for publication of this case report and the accompanying images. Copies of the written consent are available for review upon request.

\section{Abbreviations}

CCTL: Clear cell tumor of the lung; CT: Computed tomography; PAS: Periodic acid-Schiff; PEC: Perivascular epithelioid cells.

\section{Competing interests}

The authors declare that they have no competing interests.

\section{Authors' contributions}

GW performed the research. LW designed the research study. XD performed the pathological examination. GW and DZ analyzed the data. All authors read and approved the final manuscript.

\section{Acknowledgements}

The authors thank Xi Zhang for assisting in the preparation of this paper.

\section{Author details}

'Department of Radiology, Xinqiao Hospital, Third Military Medical University, Chongqing 400037, China. 'Department of Pathology, Xinqiao Hospital, Third Military Medical University, Chongqing 400037, China.

Received: 3 November 2012 Accepted: 19 September 2013

Published: 1 October 2013

\section{References}

1. Liebow AA, Castleman B: Benign "clear cell tumors" of the lung. Am J Pathol 1963, 43:13-14.

2. Bonetti F, Pea M, Martignoni G, Doglioni C, Zamboni G, Capelli P, Rimondi $P$, Andrion A: Clear cell ("sugar") tumor of the lung is a lesion strictly related to angiomyolipoma - the concept of a family of lesions characterized by the presence of the perivascular epithelioid cells (PEC). Pathology 1994, 26:230-236.

3. Hornick JL, Fletcher CD: PEComa: what do we know so far? Histopathol 2006, 48:75-82.

4. Mizobuchi T, Masahiro N, Iwai N, Kohno H, Okada N, Nakada S: Clear cell tumor of the lung: surgical and immunohistochemical findings. Gen Thorac Cardiovasc Surg 2010, 58:243-247.

5. Liebow AA, Castleman B: Benign clear cell "sugar" tumors of the lung. Yale J Biol Med 1971, 43:213-222.

6. Gaffey MJ, Mills SE, Zarbo RJ, Weiss LM, Gown AM: Clear cell tumor of the lung. Immunohistochemical and ultrastructural evidence of melanogenesis. Am J Surg Pathol 1991, 15:644-653. 
7. Andrion A, Mazzucco G, Gugliotta P, Monga G: Benign clear cell (sugar) tumor of the lung: a light microscopic, histochemical, and ultrastructural study with a review of the literature. Cancer 1985, 56:2657-2663.

8. Santana AN, Nunes FS, Ho N, Takagaki TY: A rare cause of hemoptysis: benign sugar (clear) cell tumor of the lung. Eur J Cardiothorac Surg 2004, 25:652-654.

9. Policarpio-Nicolas ML, Covell J, Bregman S, Atkins K: Fine needle aspiration cytology of clear cell "sugar" tumor (PEComa) of the lung: report of a case. Diagn Cytopathol 2008, 36:89-93.

10. Kavunkal AM, Pandiyan MS, Philip MA, Parimelazhagan KN, Manipadam MT, Cherian VK: Large clear cell tumor of the lung mimicking malignant behavior. Ann Thorac Surg 2007, 83:310-312.

11. Hironaka M, Fukayama M: Regional proliferation of HMB-45-positive clear cells of the lung with lymphangioleiomyomatosis-like distribution, replacing the lobes with multiple cysts and a nodule. Am J Surg Pathol 1999, 23:1288-1293.

12. Gora-Gebka M, Liberek A, Bako W, Szumera M, Korzon M, Jaskiewicz K: The "sugar" clear cell tumor of the lung-clinical presentation and diagnostic difficulties of an unusual lung tumor in youth. J Pediatr Surg 2006, 41:e27-e29.

13. Zarbis N, Barth TF, Blumstein NM, Schelzig H: Pecoma of the lung: a benign tumor with extensive ${ }^{18} \mathrm{~F}$-2-deoxy-D-glucose uptake. Interact Cardiovasc Thorac Surg 2007, 6:676-678.

14. Sen S, Senturk E, Kuman NK, Pabuscu E, Kacar F: PEComa (clear cell "sugar" tumor) of the lung: a benign tumor that presented with thrombocytosis. Ann Thorac Surg 2009, 88:2013-2015.

15. Yan B, Yau EX, Petersson F: Clear cell 'sugar' tumor of the lung with malignant histological features and melanin pigmentation - the first reported case. Histopathology 2011, 8:498-500.

16. Adachi Y, Kitamura Y, Nakamura H, Taniguchi Y, Miwa K, Horie Y, Hayashi K: Benign clear (sugar) cell tumor of the lung with CD1a expression. Pathol Int 2006, 56:453-456.

17. Kim WJ, Kim SR, Choe YH, Lee KY, Park SJ, Lee HB, Chung MJ, Jin GY, Lee YC: Clear cell "sugar" tumor of the lung: a well-enhanced mass with an early washout pattern on dynamic contrast-enhanced computed tomography. J Korean Med Sci 2008, 23:1121-1124.

18. Wills JS, Hewes AC: Benign clear cell tumor of the lung: a cautionary tale. Urol Radiol 1981, 2:255-257.

19. Takanami I, Kodaira S, Imamura T: The use of transbronchial lung biopsy to establish a diagnosis of benign clear cell tumor of the lung: report of a case. Surg Today 1998, 28:985-987.

20. Papla B, Demczuk S, Malinowski E: Benign clear-cell "sugar" tumor of the lung - a case report. Pol J Pathol 2003, 54:183-185.

21. Jordá Aragón C, Froufe Sánchez A, Padilla AJ: Benign clear cell tumor of the lung. Arch Bronconeumol 2005, 41:59.

22. Hirata T, Otani T, Minamiguchi S: Clear cell tumor of the lung. Int J Clin Oncol 2006, 11:475-477.

23. Edelweiss M, Gupta N, Resetkova E: Preoperative diagnosis of clear cell "sugar" tumor of the lung by computed tomography-guided fine-needle biopsy and core-needle biopsy. Ann Diagn Pathol 2007, 11:421-426.

24. Vijayabhasker R, Mehta SS, Deodhar KK, Pramesh CS, Mistry RC: PEComa of the lung. J Cancer Res Ther 2010, 6:109-111.

25. Han B, Jiang G, Wang H, He W, Liu M, Song N: Benign clear cell tumor of the lung. Ann Thorac Surg 2010, 89:2012-2014.

26. Kalkanis A, Trianti M, Psathakis K, Mermigkis C, Kalkanis D, Karagkiouzis G, Razou A, Tsintiris $\mathrm{K}$ : A clear cell tumor of the lung presenting as a rapidly growing coin lesion: is it really a benign tumor? Ann Thorac Surg 2011, 91:588-591

27. Gaffey MJ, Mills SE, Askin FB, Ross GW, Sale GE, Kulander BG, Visscher DW, Yousem SA, Colby TV: Clear cell tumor of the lung. A clinicopathologic, immunohistochemical, and ultrastructural study of eight cases. Am J Surg Pathol 1990, 14:248-259.

28. Travis WD, Brambilla E, Müller-Hermelink HK, Harris CC: World Health Organization Classification of Tumors. Pathology and Genetics of Tumors of the Lung, Pleura, Thymus and Heart. Lyon: IARC Press; 2004:118.
29. Cavazza A, Sgarbi G, Ferrari G, Putrino I, Gardini G: Clear cell tumor of the lung: description of a case $1 \mathrm{~mm}$ in diameter ("micro-sugar tumor"). Pathologica 2001, 93:556-560.

30. Sale GE, Kulander BG: "Benign" clear-cell tumor (sugar tumor) of the lung with hepatic metastases ten years after resection of pulmonary primary tumor. Arch Pathol Lab Med 1988, 112:1177-1178.

doi:10.1186/1477-7819-11-247

Cite this article as: Wang et al:: Clear cell tumor of the lung: a case report and literature review. World Journal of Surgical Oncology 2013 11:247.

\section{Submit your next manuscript to BioMed Central and take full advantage of:}

- Convenient online submission

- Thorough peer review

- No space constraints or color figure charges

- Immediate publication on acceptance

- Inclusion in PubMed, CAS, Scopus and Google Scholar

- Research which is freely available for redistribution 